TITLE:

\title{
A MORPHOMETRIC STUDY OF VELELLA (HYDROZOA) FROM DIFFERENT OCEANS
}

$\operatorname{AUTHOR}(\mathrm{S})$ :

Bieri, Robert

\section{CITATION:}

Bieri, Robert. A MORPHOMETRIC STUDY OF VELELLA (HYDROZOA) FROM DIFFERENT OCEANS. PUBLICATIONS OF THE SETO MARINE BIOLOGICAL LABORATORY 1977, 24(1-3): 59-62

ISSUE DATE:

1977-11-30

URL:

http://hdl.handle.net/2433/175958

RIGHT: 


\title{
A MORPHOMETRIC STUDY OF VELELLA (HYDROZOA) FROM DIFFERENT OCEANS
}

\author{
ROBERT BIERI \\ Antioch College, Yellow Springs, Ohio 45387
}

With Text-figures 1-2 and Table 1

When Lesson finished describing sixteen species of Velella in 1843, Linne's Velella velella and Forskal's Velella spirans (1775) were lost in a sea of thirty different namesEscholts having contributed eight of them in a single paper in 1829. Chun (1897) reduced the confusion by recognizing a single species, $V$. spirans, from the Atlantic and suggested the several forms described from the Pacific were also a single species.

According to Bigelow (1911), Schneider (1898) then reduced the number of species to one, world-wide. On the basis of the ratio of length to width and the shape of the "shell" or skeleton, Bigelow (1911) recognized two species as valid, Velella velella in the Atlantic and Velella lata in the Pacific. Because of a paucity of material he left the Indian Ocean as "mar incognito". Moser in 1925 reverted to Chun's nomenclature. Then in 1937 after Bigelow and Sears found 36 intermediate specimens of Velella from the Mediterrancan, intermediate to the Atlantic and Pacific velellas in terms of length-width ratio, these species were again lumped into one world-wide species-the Indian Ocean again unknown. Since then practice has varied, some workers recognizing one world-wide species, others recognizing two species. For example Totten (1954) retained the systematics of Bigelow and Sears, that is, he recognized a single world-wide species. After his study of the extensive Vitias material, Savilov (1969) in his monograph on the Pacific pleuston, though admitting the existence of two different forms, felt compelled to recognize only one variable species, Velella velella.

Although there are apparently world-wide pan-tropical species in the plankton, the present brief study indicates that in Velella different genetic stocks if not species can be differentiated rather easily on the basis of the body proportions of width and length. More extensive work with an examination of nematocyst distribution and other morphological characteristics may show the desirability of resurrecting some of these long-buried species.

\section{Methods}

Velella were preserved in dilute formalin and later measured to the nearest $\mathrm{mm}$ on a ruled scale in a puddle of water. The "mantle" was fully extended by pressing Publ. Seto Mar. Biol. Lab., XXIV (1/3), 59-62, $1977 . \quad$ (Article 9) 


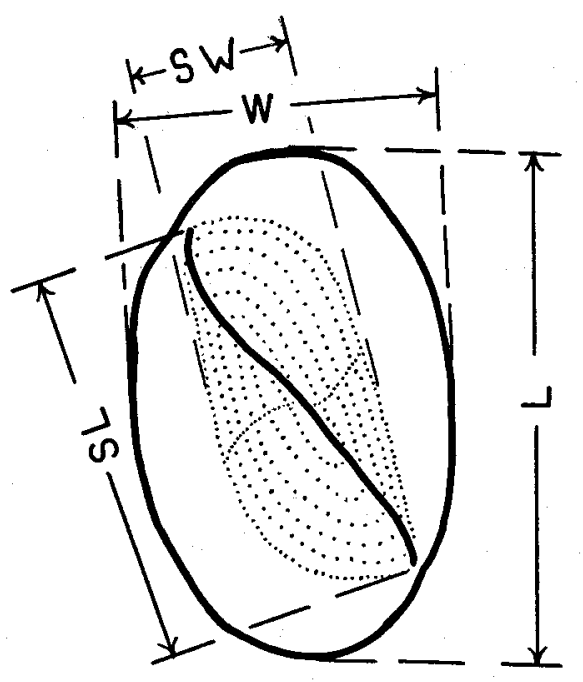

Fig. 1. Linear measurements of Velella: W, total width; L, total length; SL, skeleton length; SW, skeleton width.

down moderately on the animal. Specimens were also dissected and the "shell" or skeleton measured in the same way. Although less subject to variation due to shrinkage and to the pressure applied in pressing the specimen onto the ruled scale, the slightly greater precision achieved in measuring skeletons is probably outweighed by the time required and by the destruction of the specimen. The length and width used in this paper are shown in Fig. 1.

I measured 25 specimens from the Eastern North Pacific and combined these with data on 16 specimens reported by Bigelow (1911) from the Pacific. These data were compared to the North Atlantic data of Bigelow (1911) and Totten (1954) and to the 15 specimens reported by Totten (1954) from the South Atlantic. The data were analysed statistically using a modified regression analysis called "reduced major axes" (Kermack and Haldane, 1950).

\section{Results}

A summary of the statistical analysis is given in Table 1. Fig. 2 shows the regression lines from the statistical analysis. Each dot is an arithmetic mean. The length of the line is the range. These two statistics do not distinguish different stocks. However, the slopes of the regression lines and their positions relative to the intercept of the " $Y$ " axis are significantly different at the 95 to $99 \%$ level of confidence. The North Pacific and North Atlantic populations are significantly different in slope at the 95 to $99 \%$ level of confidence. The South Atlantic and North Atlantic populations are significantly different in slope at the $99 \%$ level of confidence. On the other hand, the North Pacific and South Atlantic populations are not significantly different in slope but are significantly different in position of 
L =length $W=$ width

$\mathrm{OR}=$ overall range
Table 1

$\mathrm{a}=$ slope

$\mathrm{b}=\mathrm{Y}$ or width intercept

$\mathrm{V}=$ coefficient of variation =correlation coefficient, length to width

\begin{tabular}{|c|c|c|c|c|c|c|}
\hline Statistic & & Pacific Velella & & N. Atl. Velella & & S. Atl. Velella \\
\hline $\mathbf{N}$ & .............. & 41 & ............. & 38 & ............ & 15 \\
\hline L, mear & & 39.95 & & 36.4 & & 20.4 \\
\hline $\mathrm{W}$, mear & & 18.90 & & 13.2 & & 9.86 \\
\hline$\sigma \mathrm{L}$ & ............. & 16.95 & ............. & 20.1 & .............. & 5.85 \\
\hline$V_{L}$ & & 42.5 & & 55.4 & & 28.6 \\
\hline$a \mathrm{~W}$ & & 7.30 & & 6.62 & & 2.55 \\
\hline$V_{w}$ & .............. & 38.5 & .............. & 50.2 & .............. & 25.8 \\
\hline r & & 0.988 & & 0.976 & & 0.957 \\
\hline $\mathrm{OR}_{\mathrm{L}}$ & & $20-104$ & & $13-82$ & & $8.0-27.5$ \\
\hline ORw & .............. & $10-46$ & .............. & $5.5-30$ & .............. & $4.0-13$ \\
\hline $\mathrm{a}$ & & 0.431 & & 0.329 & & 0.436 \\
\hline$\sigma \mathrm{a}$ & & 0.0104 & & 0.0116 & & 0.0319 \\
\hline $\mathrm{b}$ & ….......... & 1.69 & (............. & 1.21 & .............. & 0.968 \\
\hline
\end{tabular}

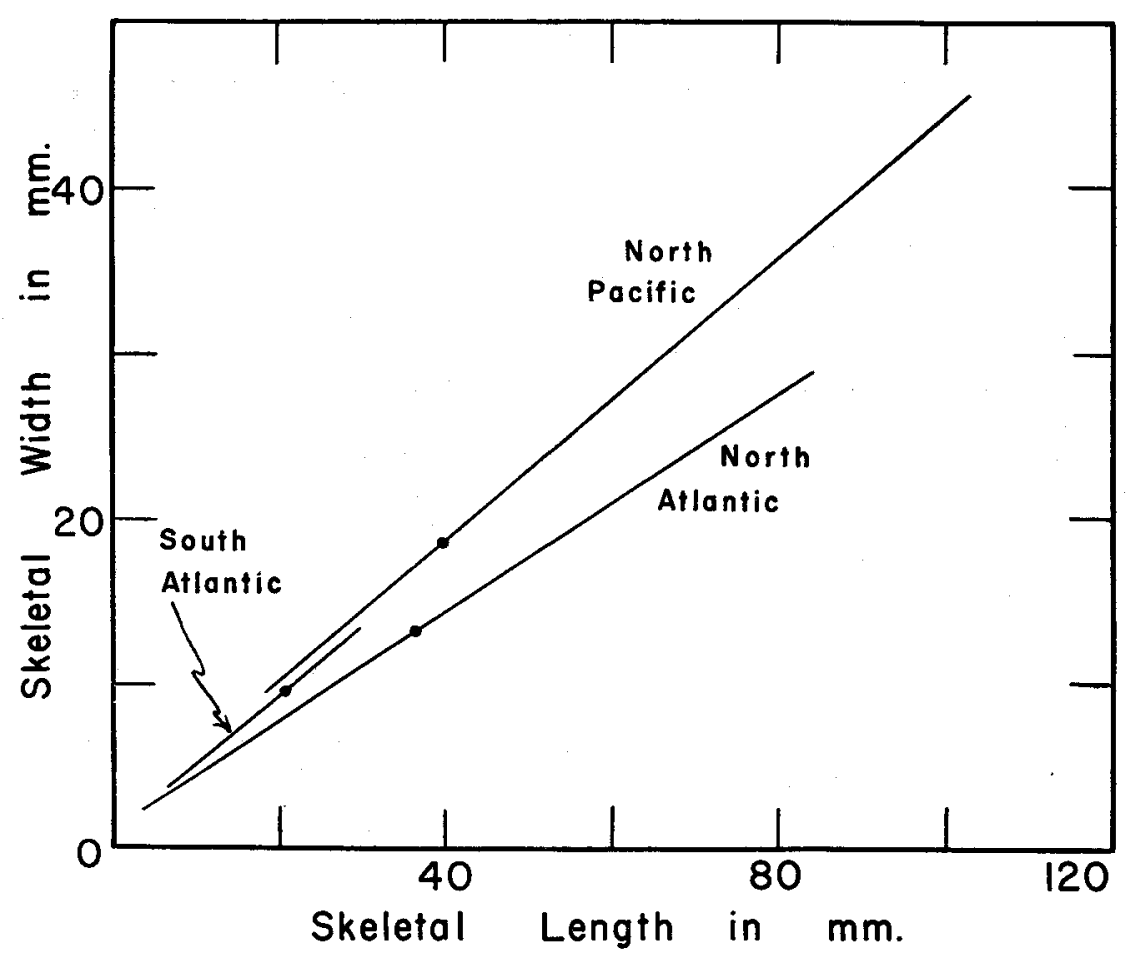

Fig. 2. Regression lines of three populations of Velella. Dots are arithmetic means, lines show the range. 
the "Y" intercept at the $99 \%$ level of confidence. The different slopes and intercept positions are most easily explained as due to different genetic stocks. Very likely differences in length-width proportion would give different sailing characteristics and thus enhance genetic isolation.

\section{Conclusions}

Populations of Velella from different oceans have different length-width proportions and growth patterns. This is shown by very significantly different slopes and positions of lines of regression. Considering length to width ratios only, South Atlantic velellas are more closely related to North Pacific velellas than they are to North Atlantic velellas. The differences between various populations of Velella probably reflect different genetic stocks. Local populations of Velella should be reevaluated to determine the desirability of resurrecting some old species names and more importantly to shed light on the degree of genetic isolation between stocks of Velella. Clearly understanding the degree of genetic isolation is crucial to an understanding of their ecology and the ecology of much of the blue-water sea-surface community that is dependent on Velella.

\section{LITERATURE CITED}

Bigelow, H.B. 1911. The Siphonophorae, Reports on the Scientific Results of the Expedition to the Eastern Tropical Pacific by the U.S. Fish Comm. Steamer "Albatross" 1904-1905. Mem. Mus. Comp. Zool. Harv. Coll., 38: 173-402.

Bigelow, H.B. and M. Sears 1937. Siphonophorae. Rep. Danish Oceanogr. Exped. 1908-1910 to the Medit. and Adj. Seas. vol. 2, Biol., H 2: 1-144.

Chun, C. 1897. Die Siphonophoren der Plankton Exped. Ergeb. Plankton Exped., Vol. 2

Escholtz, F. 1829. System der Acalephen, line Ausführliche Beschreibung Allen Medusenartigen Strahlthiere. F. Dümmler, Berlin, 190 pp.

Forskal, P. 1775. Descriptiones animalum...quae in itenere orientali observavit, post mortem editit Carstem Niebuhr. Hauniae, 36 pp.

Kermak, K.A. and J.B.S. Haldane 1950. Organic correlation and allometry. Biometrika, Vol. 37: 30-41.

Lesson, R.P. 1843. Histoire naturelle des zoophytes Acalèphes. Paris, 596 pp.

Moser, F. 1925. Die Siphonophoren der Deutschen Südpolar Expedition 1901-03. Deut. Südpolar Exped. Vol. 17 (Zool. 9): 1-541.

Savilov, A.I. 1968. Part II. Pleuston of the Pacific Ocean. In Biology of the Pacific Ocean, edited by L.A. Zenkevich, Nauka, Moscow, 264-353 (in Russian, transl. Nat. Tech. Info. Serv., U.S. Dept. Commerce).

Totten, A.K. 1954. Siphonophora of the Indian Ocean together with systematic and biological notes on related specimens from other oceans. Discovery Repts., Vol. 27: 1-162. 